EPIDEMIOLOGY

\title{
Association of birth weight with adult lung function: findings from the British Women's Heart and Health Study and a meta-analysis
}

\author{
D A Lawlor, S Ebrahim, G Davey Smith
}

See end of article for authors' affiliations

Correspondence to:

Dr D A Lawlor, Department of Social Medicine University of Bristol, Bristol BS8 2PR, UK; d.a.lawlor@ bristol.ac.uk

Received 13February 2005 Accepted 6 July 2005

Published Online First 29 July 2005
Background: The aim of this study was to examine the associations between birth weight and lung function in a cohort of women aged 60-79 years and to combine these results with those from other published studies in a systematic review and meta-analysis.

Methods: The associations of self-reported birth weight with adult lung function (forced expiratory volume in 1 second $\left(F E V_{1}\right)$, forced vital capacity $(F V C)$ and forced expiratory flow rate during mid expiration $\left(\mathrm{FEF}_{25-75}\right)$, all measured using standard procedures, were assessed in a cross sectional study of 2257 British women aged 60-79 years. A detailed literature search was used to identify all published studies of the association, and meta-analysis was used to pool the results from our study and all published studies. Results: There were positive linear associations between birth weight and all three measures of lung function in simple age and examining nurse adjusted regression models. However, with adjustment for height (squared), all three associations attenuated towards the null: adjusted (age, nurse, height ${ }^{2}$ ) change in $\mathrm{FEV}_{1}$ per $1 \mathrm{~kg}$ birth weight was $0.01 \mathrm{I}(95 \% \mathrm{Cl}-0.02$ to 0.04$)$; in $\mathrm{FVC}$ was 0.02 I $(95 \% \mathrm{Cl}-0.02$ to 0.07), and in $\mathrm{FEF}_{25-75}$ was $0.00 \mathrm{l}(95 \% \mathrm{Cl}-0.04$ to 0.04$)$. Further adjustment for life course socioeconomic position, adult body mass index, and smoking did not alter these associations. The results were similar among life long non-smokers and those who had ever smoked. A meta-analysis of eight studies of adults suggested that there was a positive association between birth weight and $\mathrm{FEV}_{1}$ : pooled increase in $\mathrm{FEV}_{1}$ per $1 \mathrm{~kg}$ in birth weight $0.048 \mathrm{I}(95 \% \mathrm{Cl} 0.026$ to 0.070$)$ adjusted for age, smoking, and height (or height squared). There was no evidence of small study bias in this meta-analysis.

Conclusions: There is a modest positive association between birth weight and lung function which indicates that intrauterine factors might have a role in lung development.
$\mathrm{P}$ oor lung function in adulthood is associated with increased risk of cardiovascular disease and all-cause mortality even among life long non-smokers, but the explanation for these associations is unclear. ${ }^{1-3}$ It is possible that they reflect early life exposures that influence lung growth and development as well as adult disease risk. The fetal origins hypothesis proposes that the fetus adapts its growth rate as a response to changes in nutrient and oxygen supply. These adaptations affect growing organs and hormonal and metabolic pathways. ${ }^{4}$ Thus, a reduced supply of nutrients to the fetus may result in low birth weight and, depending on the timing, may result in specific detrimental effects to growing organs such as the liver, pancreas, heart and lungs. ${ }^{45}$ Birth weight has been shown to be inversely associated with cardiovascular disease risk and this association is independent of socioeconomic position, a range of cardiovascular risk factors, and adult body size. ${ }^{46}$ The association between poor lung function and cardiovascular disease may therefore be partly related to intrauterine factors that affect fetal growth, programme cardiovascular disease, and also affect lung growth and development. ${ }^{5}$

Several studies have examined the association between birth weight and lung function with some, ${ }^{7-11}$ though not all, ${ }^{12-16}$ finding a positive association. These conflicting results may be due to the small sample sizes of most studies and differences between studies in the range of potential confounding factors that were taken into account. Importantly, several of the studies did not control for childhood socioeconomic position, ${ }^{10}{ }^{12-14}$ despite this being strongly related to both birth weight ${ }^{17}$ and lung function. ${ }^{18}$ While most studies adjusted in multivariable models for adult smoking status, because of the very strong association between smoking and lung function stratified analyses would provide better evidence that any association was not largely explained by smoking. Finally, it has been suggested that the inverse association is largely due to poor lung function in very low birth weight infants and that the results of some studies claiming an inverse association across the birth weight distribution are largely driven by the effect in very low birth weight infants. ${ }^{13}$

The aim of this study was to examine the associations between birth weight and lung function in a cohort of over 2200 women aged 60-79 and to combine these results with those from other published studies in a systematic review and meta-analysis in order to obtain a precise estimate of the strength of association between birth weight and lung function.

\section{METHODS}

\section{Participants}

Data from the British Women's Heart and Health Study were used. Full details of the selection of participants and measurements used in the study have been previously reported. ${ }^{18} 19$ Between 1999 and 2001, 4286 women aged 60-79 years who were randomly selected from 23 British towns were interviewed, examined, completed medical questionnaires, and had detailed reviews of their medical records. These women have been followed up over a median

Abbreviations: $\mathrm{FEF}_{25-75}$, forced expiratory flow rate during mid expiration; $\mathrm{FEV}_{1}$, forced expiratory volume in 1 second; $\mathrm{FVC}$, forced vital capacity 
of 4 years by flagging with the NHS central register for mortality data, two yearly review of their medical records, and a mailed 3 year follow up health questionnaire (Q3) sent to all surviving participants between March and September 2003. Of the 4108 survivors, 3704 (90\%) responded to this questionnaire. Local ethics committee approvals were obtained for the study.

\section{Measurements \\ Lung function tests}

Lung function tests were carried out using a digital meter Vitalograph with an attached printout of forced vital capacity (FVC), forced expiratory volume in 1 second $\left(\mathrm{FEV}_{1}\right)$, and forced mid expiratory flow rate $\left(\mathrm{FEF}_{25-75}\right)$. The Vitalograph was calibrated each day using a 1 litre syringe and automated so that results were adjusted for ambient temperature. For each assessment a research nurse demonstrated the technique to the participant. The participants then performed some practice efforts. They were then required to perform a minimum of three reproducible FVC measures (within 5\% of maximum FVC produced). The output that produced the highest sum of FVC and $\mathrm{FEV}_{1}$ were used in the analyses. Women who could not perform three reproducible measures or who were unable to attempt the lung function assessment were excluded. All assessments were carried out by one of five research nurses who were trained to carry out the assessment in a similar manner.

\section{Birth weight}

In both the baseline questionnaire and the follow up Q3 questionnaire women were asked to record their birth weight in pounds and ounces, which were converted to kilograms. In Q3 only, women were also asked to indicate into which of five birth weight categories (of $2 \mathrm{lb}$ size) they believed their birth weight fell. In previous publications we have shown that self-reported birth weight at baseline had a similar distribution to British women of a similar age for whom there were hospital records of birth weight available, and that the associations between self-reported birth weight at baseline and adult anthropometric measures were in the same direction and of a similar magnitude to what would be predicted from recorded measures. ${ }^{20}{ }^{21}$ For those women who provided birth weights rather than category of birth weight, at both baseline and Q3 $(\mathrm{N}=690)$ the two measures were highly correlated (Pearson's correlation coefficient 0.97 ) with a mean difference between the two measures (95\% limits of agreement) of $0.013(-0.379$ to +0.405$) \mathrm{kg}$. For those women who also indicated which birth weight category they fell into $(\mathrm{N}=670)$, all but 12 showed absolute consistency between these two means of asking about birth weight. For this analysis a continuous birth weight variable has been generated for all women by using primarily the baseline self-report, substituting this for the Q3 continuous self-report if there was no baseline report and then substituting for the mid point of the categorical values for those with no continuous report $(\mathrm{N}=853$ of 2431 with any birth weight data). The mean birth weights for those providing a continuous value was identical to that calculated for those providing just a categorical value $(3.30(0.84) v 3.31(0.55))$.

\section{Other measurements}

As previously reported, information on the following 10 indicators of life course socioeconomic position were obtained from the baseline questionnaire:

- occupational social class of father (categorised into six categories using the Registrar General's classification from I (professional) to V (unskilled manual));

- whether childhood home had a bathroom;
- whether childhood home had a hot water supply;

- whether participant shared a bedroom as a child;

- family access to a car when participant was a child;

- age at leaving full time education (collapsed into four categories: <15, 15-17, 18-21, and >21 years);

- adult occupational social class of head of household (categorised into six categories using the Registrar General's classification from I (professional) to $\mathrm{V}$ (unskilled manual));

- car access in adulthood;

- pension arrangements (state only, occupational and state, private and state, all three of occupational, private and state);

- house ownership (owner occupied, private renting, living with family, council (public) rented). ${ }^{18}$

Smoking history (never, past, and current including amount and details of starting and quitting), marital status, and smoking history (never, past, and current including amount and details of starting and quitting) of husbands/ long term partners were self-reported either at the research nurse interview or in the mailed questionnaires. Standing height was measured without shoes using a Harpenden Stadiometer recording to the nearest millimetre, and weight (to nearest $0.5 \mathrm{~kg}$ ) was measured in light clothing using a Schoen portable scale that was calibrated each morning.

\section{Statistical analysis}

Analysis of variance was used to assess between-nurse variation in lung function measurements. A series of linear regression models were used to estimate the association between birth weight and each measure of lung function. In the basic models adjustment was made for examining nurse and age. In the next model height squared was added to the basic model. The square of height was used because, in an earlier study of the association between stature and lung function, it was concluded that a proportional model best described the association ${ }^{22}$ and in our data we found that this was also the case (in a regression model with height this explained $12 \%$ of the variation in $\mathrm{FEV}_{1}$ whereas height squared explained $17 \%$ ). Additional adjustment was then made for all indicators of socioeconomic position from across the life course and in the final model the women's adult smoking status was also added. In order to determine whether the association was linear, we first examined the association with three indicator variables for the quarters of birth weight and then compared this with a model in which the birth weight quarters were entered as a continuous variable. We computed a likelihood ratio test to compare these two nested models. In addition, we examined the association in a restricted sample of women excluding those in the lowest quarter of the birth weight distribution and who may have had low birth weight because of prematurity. To determine whether there was any interaction between birth weight and either adult height or adult body mass index, all of these variables were split into quarters and stratum specific associations examined. F-tests were computed to determine statistical evidence of an interaction between birth weight and adult anthropometric measurements in their associations with lung function. Because of the strong association between adult smoking and lung function, simple adjustment for smoking in regression models may be insufficient to account for its potential confounding effects. As a result, the regression models were repeated stratified by smoking status. In all analyses robust confidence intervals were estimated which take into account the clustering between participants from the same towns. 
To correct for the possibility that our estimates of the association between birth weight and lung function would be diluted by our use of self-reported birth weight, we undertook a series of sensitivity analyses in which we used the reported correlation coefficients of the association between self-report and medical records of birth weight to correct our estimate. ${ }^{23}$ In these analyses we used intraclass correlations of 0.6 and 0.9 to correct our regression coefficients, ${ }^{23}$ multiplying by the inverse of these coefficients. All analyses were undertaken using Stata version 8.

\section{Meta-analysis}

A search of Medline and Embase (up to December 2004) was undertaken using the search terms "lung function" OR "FEV\$" OR "FVC\$" OR "FEF\$" OR "Spirometr\$" AND "birth weight" OR "birth size" OR "intrauterine growth" OR "small for gestational age" OR "fetal origins\$" OR "Barker's hypothesis". Bibliographies were searched for additional references. Studies were included in the systematic review if they examined the association between birth weight and lung function assessed in adulthood (defined as age 18 years or older). We included studies that were written in any language. Studies were included in the meta-analysis if a regression coefficient of the association of measures of $\mathrm{FEV}_{1}$ on birth weight were presented, could be estimated, or was obtained through contact with the authors. Meta-analyses of other lung function outcomes were not undertaken because there were too few studies with outcomes other than $\mathrm{FEV}_{1}$. We decided a priori to assume heterogeneity between studies as some studies were in male populations only and our study was in a female population. Fetal growth rates differ between the sexes and in other areas it has been suggested that this results in different effects of fetal programming between the sexes. ${ }^{24}$ Random effects meta-analysis was therefore undertaken. ${ }^{25}$ Funnel plots were examined and statistical evidence of small study bias was assessed with Egger and Begg tests. ${ }^{25}$ All analyses were undertaken using Stata version 8.

\section{RESULTS}

Of the 4286 participants 3911 (91\%) completed adequate lung function measures and 2431 (57\%) provided selfreported data on their birth weight. Those who were unable to complete adequate lung function measures were older (mean (SD) age $69.8(5.7)$ years $v 68.8(5.5)$ years, $\mathrm{p}=0.001$ ) and more likely to have ever been smokers $(61.7 \%$ (95\% CI
56.6 to 66.6$) \vee 53.5 \%$ (95\% CI 52.0 to 55.1$), \mathrm{p}=0.003$ ). Women who provided self-reported data on birth weight had better lung function tests than those who did not (mean (SD) values in those with birth data compared with those without these data were: $2.02(0.5)$ l $v 1.19(0.5) \mathrm{l}, \mathrm{p}<0.001$ for $\mathrm{FEV}_{1}$; $2.86(0.8) \mathrm{l} v 2.73(0.7) \mathrm{l}, \mathrm{p}<0.001$ for FVC, and $1.50(0.7) \mathrm{l} v$ 1.37 (0.7) l, $\mathrm{p}<0.001$ for $\mathrm{FEF}_{25-75}$ ). Women who provided birth weights were also less likely to be from manual social classes in childhood $(77.2 \% v 83.7 \%, \mathrm{p}<0.001)$ and adulthood $(54.8 \% \vee 60.6 \%, \mathrm{p}<0.001)$, were less likely to be current smokers $(10.6 \% v 13.0 \%, \mathrm{p}=0.02)$, and were taller as adults (1591.4 mm $v 1582.9 \mathrm{~mm}, \mathrm{p}<0.001$ ). There was evidence of some difference between the nurses in lung function assessments: mean (SD) $\mathrm{FEV}_{1}$ for nurse 1 was 2.00 (0.53) l; for nurse 2 was $1.92(0.46)$ l; for nurse 3 was 2.02 (0.52) l; for nurse 4 was 2.01 (0.50) l; and for nurse 5 was 1.96 (0.50) l, p (analysis of variance for difference in means $)=0.05$. All lung function measures have therefore been adjusted for examining nurse by including examining nurse as an indicator variable in all analyses.

In total, 2257 women (53\%) had complete data on both lung function measures and birth weight and all remaining analyses are for these 2257 women only. Birth weight was similar in those women who were able to perform lung function tests and those who were not $(3.31 \mathrm{~kg} v 3.32 \mathrm{~kg}$, $\mathrm{p}=0.4)$. Among the 2257 women included in further analyses the mean (SD) birth weight was $3.31(0.76) \mathrm{kg}$.

Tables $1-3$ show the associations between birth weight and each measure of lung function. In the basic model with adjustment for examining nurse and age only, birth weight was positively and linearly associated with all three measures of lung function. These associations were linear across the birth weight distribution and not simply driven by low function in those of very low birth weight. However, all of these associations attenuated towards the null with adjustment for the square of height. Further adjustment for life course socioeconomic position and adult body mass index and smoking did not substantially alter the height adjusted coefficients. There was no evidence of non-linear associations (all p values $>0.4$ ) and associations were similar among women reporting their birth weights in the lowest quarter of the distribution to those in all other women. There was no evidence of any interactions between birth weight and either adult height or body mass index in their associations with the different lung function measurements (all $p$ values $>0.6$ ).

Table 1 Multivariable associations of birth weight with FEV

\begin{tabular}{|c|c|c|c|c|}
\hline & \multicolumn{4}{|c|}{ Difference $\left(95 \%\right.$ confidence inferval) in $\mathrm{FEV}_{1}$ (I) } \\
\hline & Model $1^{*}$ & Model $2 \dagger$ & Model 3‡ & Model 4§ \\
\hline $\begin{array}{l}\text { Lowest quarter birth weight, } \\
\text { range 739-2826 g ( } N=746)\end{array}$ & Reference & Reference & Reference & Reference \\
\hline $\begin{array}{l}\text { 2nd quarter birth weight, } \\
\text { range } 2827-3352 \mathrm{~g}(\mathrm{~N}=476)\end{array}$ & $0.07(0.00$ to 0.13$)$ & $0.01(-0.05$ to 0.07$)$ & $-0.01(-0.07$ to 0.05$)$ & $-0.01(-0.07$ to 0.05$)$ \\
\hline $\begin{array}{l}\text { 3re quarter birth weight, } \\
\text { range } 3353-3735 \mathrm{~g}(\mathrm{~N}=774)\end{array}$ & 0.11 (0.05 to 0.15$)$ & $0.02(-0.03$ to 0.08$)$ & $0.02(-0.03$ to 0.07$)$ & $0.02(-0.03$ to 0.07$)$ \\
\hline $\begin{array}{l}\text { Highest quarter birth weight, } \\
\text { range } 3736-5909 \mathrm{~g}(\mathrm{~N}=435)\end{array}$ & $0.13(0.06$ to 0.19$)$ & $0.01(-0.06$ to 0.07$)$ & $0.00(-0.06$ to 0.06$)$ & $0.00(-0.07$ to 0.06$)$ \\
\hline Per $1 \mathrm{~kg}$ birth weight & $0.07(0.04$ to 0.10$)$ & $0.01(-0.02$ to 0.04$)$ & $0.01(-0.02$ to 0.04$)$ & $0.01(-0.02$ to 0.04$)$ \\
\hline $\mathrm{p}$ linear trend & $<0.001$ & 0.48 & 0.47 & 0.42 \\
\hline p non-linear association & 0.43 & 0.27 & 0.55 & 0.69 \\
\hline $\begin{array}{l}\text { Per } 1 \mathrm{~kg} \text { excluding those in } \\
\text { lowest birth weight guarter }\end{array}$ & $0.04(-0.02$ to 0.09$)$ & $0.00(-0.05$ to 0.05$)$ & $0.00(-0.05$ to 0.05$)$ & $0.01(-0.04$ to 0.06$)$ \\
\hline
\end{tabular}

$\mathrm{FEV}_{1}$, forced expiratory volume in 1 second.

*Model 1: adjusted for age and examining nurse.

†Model 2: adjusted for age, examining nurse and height squared.

$\ddagger$ Model 3: adjusted for age, examining nurse, height squared, father's occupational social class, whether childhood house had a bathroom, whether childhood house had hot water, family access to a car in childhood, whether the participant shared a bedroom as a child, age at leaving full time education, adult occupational social class, adult car access, adult home ownership, pension arrangements.

§Model 4: adjusted for all factors in model 3 and adult smoking 
Table 2 Multivariable associations of birth weight with FVC

\begin{tabular}{|c|c|c|c|c|}
\hline & \multicolumn{4}{|c|}{ Difference $(95 \%$ confidence interval) in FVC (I) } \\
\hline & Model $1^{*}$ & Model $2 \dagger$ & Model 3‡ & Model 4§ \\
\hline $\begin{array}{l}\text { Lowest quarter birth weight, } \\
\text { range } 739-2826 \mathrm{~g}(\mathrm{~N}=746)\end{array}$ & Reference & Reference & Reference & Reference \\
\hline $\begin{array}{l}\text { 2nd quarter birth weight, } \\
\text { range } 2827-3352 \mathrm{~g}(\mathrm{~N}=476)\end{array}$ & $0.15(0.04$ to 0.26$)$ & $0.07(-0.04$ to 0.17$)$ & $0.04(-0.06$ to 0.15$)$ & $0.04(-0.06$ to 0.14$)$ \\
\hline $\begin{array}{l}\text { 3rd quarter birth weight, range 3353- } \\
3735 \mathrm{~g}(\mathrm{~N}=774)\end{array}$ & 0.18 (0.09 to 0.27$)$ & $0.06(-0.03$ to 0.17$)$ & $0.06(-0.03$ to 0.15$)$ & $0.06(-0.03$ to 0.15$)$ \\
\hline $\begin{array}{l}\text { Highest quarter birth weight, } \\
\text { range } 3736-5909 \mathrm{~g}(\mathrm{~N}=435)\end{array}$ & $0.19(0.08$ to 0.30$)$ & $0.02(-0.08$ to 0.13$)$ & $0.01(-0.09$ to 0.12$)$ & $0.02(-0.09$ to 0.12$)$ \\
\hline Per $1 \mathrm{~kg}$ birth weight & $0.10(0.05$ to 0.15$)$ & $0.02(-0.03$ to 0.07$)$ & $0.02(-0.03$ to 0.07$)$ & $0.02(-0.02$ to 0.07$)$ \\
\hline $\mathrm{p}$ linear trend & $<0.001$ & 0.42 & 0.41 & 0.31 \\
\hline p non-linear association & 0.24 & 0.19 & 0.35 & 0.34 \\
\hline $\begin{array}{l}\text { Per } 1 \mathrm{~kg} \text { excluding those in } \\
\text { lowest birth weight quarter }\end{array}$ & $0.02(-0.07$ to 0.11$)$ & $-0.04(-0.13$ to 0.05$)$ & $-0.02(-0.11$ to 0.07$)$ & $-0.01(-0.10$ to 0.08$)$ \\
\hline \multicolumn{5}{|c|}{$\begin{array}{l}\text { FVC, forced vital capacity. } \\
\text { *Model 1: adjusted for age and examining nurse. } \\
\text { †Model 2: adjusted for age, examining nurse and height squared. } \\
\text { †Model 3: adjusted for age, examining nurse, height squared, father's occupational social class, whether childhood house had a bathroom, whether childhood house had hot } \\
\text { water, family access to a car in childhood, whether the participant shared a bedroom as a child, age at leaving full time education, adult occupational social class, adult car } \\
\text { access, adult home ownership, pension arrangements. } \\
\text { §Model 4: adjusted for all factors in model } 3 \text { and adult smoking. }\end{array}$} \\
\hline
\end{tabular}

\section{Sensitivity analyses}

Using an intraclass correlation coefficient of 0.6 to correct for attenuation by errors, the associations of birth weight with lung function strengthened but remained non-significant in the fully adjusted models. The corrected fully adjusted change in $\mathrm{FEV}_{1}$ for a $1 \mathrm{~kg}$ increase in birth weight was $0.02 \mathrm{l}(95 \% \mathrm{CI}-0.01$ to 0.03$)$ and the fully adjusted change in FVC was $0.03 \mathrm{l}$ (95\% CI -0.01 to 0.06$)$. The results were unaltered from those presented in tables 1-3 using an intraclass correlation coefficient of 0.9 .

Smoking status was strongly associated with lung function. For example, $\mathrm{FEV}_{1}$ was $0.11 \mathrm{l}(95 \% \mathrm{CI}-0.15$ to -0.07$)$ lower among women who were past smokers than in never smokers and was $0.38 \mathrm{l}$ ( $95 \% \mathrm{CI}-0.45$ to -0.32 ) lower in current smokers than in never smokers in analyses adjusted for age, leg length (squared), adult and childhood social class, birth weight, and body mass index. When the analyses were repeated in strata according to smoking status, the results in women who were lifelong non-smokers and either single or married were similar to those in non-smokers and all other women. For example, the simple age and examining nurse adjusted change in $\mathrm{FEV}_{1}$ per $1 \mathrm{~kg}$ increase in birth weight among lifelong non-smokers $(\mathrm{N}=1272)$ was $0.08 \mathrm{l}$ (95\% CI 0.04 to 0.11 ), p $<0.001$ and, with additional adjustment for height squared, this attenuated to $0.02 \mathrm{l}$ (95\% CI -0.01 to 0.05 ), $\mathrm{p}=0.27$.

\section{Meta-analysis}

Ten studies ${ }^{7-11} 13-162627$ of the association between birth weight and lung function among adults were identified and these are summarised in table 4. Regression coefficients of the association of $\mathrm{FEV}_{1}$ with birth weight were either presented or obtained from investigators for seven of these studies. When the results from these seven studies were pooled with the results form the British Women's Heart and Health study, there was a positive association between birth weight and $\mathrm{FEV}_{1}$ adjusted for age, smoking, and height (or height squared) at the time of lung function measurement, with $\mathrm{FEV}_{1}$ increasing by $0.048 \mathrm{l}$ (95\% CI 0.026 to 0.070 ) for each increase of $1 \mathrm{~kg}$ birth weight (fig 1). Adjustment for other covariates as described in table 4 had also been made in some studies. There was weak statistical evidence of heterogeneity between these studies $(p=0.07)$. There was no evidence of small study bias $(p=0.1$ for Egger test and

Table 3 Multivariable associations of birth weight with $\mathrm{FEF}_{25-75}$

\begin{tabular}{|c|c|c|c|c|}
\hline & \multicolumn{4}{|c|}{ Difference $\left(95 \%\right.$ confidence interval) in $\mathrm{FEF}_{25-75}$ (I) } \\
\hline & Model $1^{*}$ & Model $2 \dagger$ & Model $3 \ddagger$ & Model 4§ \\
\hline $\begin{array}{l}\text { Lowest quarter birth weight, } \\
\text { range } 739-2826 \mathrm{~g}(\mathrm{~N}=746)\end{array}$ & Reference & Reference & Reference & Reference \\
\hline $\begin{array}{l}\text { 2nd quarter birth weight, } \\
\text { range } 2827-3352 \mathrm{~g}(\mathrm{~N}=476)\end{array}$ & $0.05(-0.04$ to 0.14$)$ & $0.01(-0.08$ to 0.10$)$ & $-0.01(-0.10$ to 0.08$)$ & $-0.01(-0.10$ to 0.08$)$ \\
\hline $\begin{array}{l}\text { 3rd quarter birth weight, } \\
\text { range } 3353-3735 \mathrm{~g}(\mathrm{~N}=774)\end{array}$ & $0.07(-0.01$ to 0.15$)$ & $0.01(-0.07$ to 0.09$)$ & 0.01 ( -0.07 to 0.09$)$ & 0.00 ( -0.08 to 0.08$)$ \\
\hline $\begin{array}{l}\text { Highest quarter birth weight, } \\
\text { range } 3736-5909 \mathrm{~g}(\mathrm{~N}=435)\end{array}$ & $0.08(-0.01$ to 0.18$)$ & $0.00(-0.09$ to 0.10$)$ & $-0.01(-0.11$ to 0.08$)$ & $-0.02(-0.12$ to 0.07$)$ \\
\hline Per $1 \mathrm{~kg}$ birth weight & 0.05 (0.01 to 0.09$)$ & $0.01(-0.03$ to 0.05$)$ & $0.01(-0.04$ to 0.05$)$ & $0.00(-0.04$ to 0.04$)$ \\
\hline$P$ linear trend & 0.03 & 0.67 & 0.78 & 0.88 \\
\hline p non-linear association & 0.91 & 0.94 & 0.99 & 0.98 \\
\hline $\begin{array}{l}\text { Per } 1 \mathrm{~kg} \text { excluding those in } \\
\text { lowest birth weight quarter }\end{array}$ & $0.04(-0.04$ to 0.11$)$ & $0.01(-0.06$ to 0.08$)$ & $0.01(-0.07$ to 0.08$)$ & 0.01 ( -0.07 to 0.08 ) \\
\hline
\end{tabular}

$\mathrm{FEF}_{25-75}$, forced expiratory flow rate during mid expiration.

*Model 1: adjusted for age and examining nurse.

†Model 2: adjusted for age, examining nurse and height squared.

¥Model 3: adjusted for age, examining nurse, height squared, father's occupational social class, whether childhood house had a bathroom, whether childhood house had hot water, family access to a car in childhood, whether the participant shared a bedroom as a child, age at leaving full time education, adult occupational social class, adult car access, adult home ownership, pension arrangements.

§Model 4: adjusted for all factors in model 3 and adult smoking. 


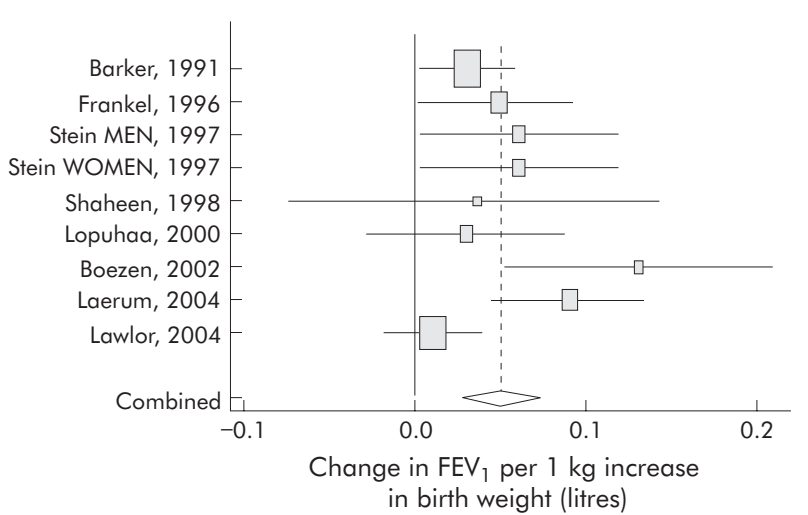

Figure 1 Meta-analysis of adult studies of the association between birth weight and forced expiratory volume in 1 second $\left(F E V_{1}\right)$ measured in adulthood. The regression coefficient (change in $\mathrm{FEV}_{1}$ (I) per increase in $1 \mathrm{~kg}$ birth weight) and $95 \%$ confidence intervals are shown for each individual study. The boxes represent the regression coefficient and the size of the box indicates the weight given to that study in the metaanalysis (greater weight given to larger studies); the horizontal lines represent $95 \%$ confidence intervals. The diamond is the pooled effect obtained from combining the coefficients of each study. The vertical points of the diamond indicate the pooled regression coefficient and the two horizontal points the lower and upper $95 \%$ confidence intervals.

$\mathrm{p}=0.2$ for Begg's test). Of the three studies for which regression coefficients could not be obtained, one found no evidence of an association between birth weight and lung function $^{13}$ while the other two found a positive linear association. ${ }^{1027}$

\section{DISCUSSION \\ Main results}

We found no association between self-reported birth weight and measures of lung function at age 60-79 years in over 2000 British women once height was taken into account. Despite being one of the largest studies to date to assess the association between birth weight and lung function in adulthood, our results were imprecise and a meta-analysis suggested a positive association between birth weight and $\mathrm{FEV}_{1}$. Exclusion of the three studies for which regression coefficients could not be obtained would be unlikely to make a major difference to this modest effect, as they also showed only small effects and would have contributed about 15\% to the weight of the meta-analysis. We considered whether the lack of adjustment for socioeconomic position in previous studies might have influenced their results. However, in the British Women's Heart and Health study further adjustment for a range of life course socioeconomic indicators, once adult height had been taken into account, did not alter the regression coefficient, suggesting that socioeconomic position is not a major confounder in this association. All of the regression coefficients included in our meta-analysis had been adjusted for height prior to pooling. Thus, despite the modest association between birth weight and adult height (Pearson's correlation coefficient in the region of $0.2-0.3$ in this and other studies ${ }^{28}{ }^{29}$ ), the effect of birth weight on adult lung function is independent of adult height.

\section{Study limitations}

Our response $(60 \%)$ is moderate but consistent with other contemporary large epidemiological surveys. ${ }^{30}$ As reported previously, participants were slightly younger than nonparticipants and less likely to have a primary care medical record of stroke or diabetes, although the prevalence of coronary heart disease and cancer did not vary between participants and non-participants. ${ }^{19}$ The associations presented here would be exaggerated if they were in the opposite direction or markedly weaker among non-participants. Our study is cross sectional. However, since the temporal nature of the association between birth weight and adult lung function is clear, reverse causality cannot explain our findings. An important limitation was the use of selfreported birth weight, and the fact that just 53\% of the original cohort had data on birth weight and lung function tests. In previous studies we have shown that recalled birth weight in the British Women's Heart and Health Study is associated with adult anthropometric measurements in the ways one would expect, and the distribution of recalled birth weights in this cohort were similar to those of recorded weights for women of a similar age in the Hertfordshire cohort and the 1946 British birth cohort. ${ }^{20} 21$ The mean (SD) self-reported birth weight of women in our study was $3.31(0.76) \mathrm{kg}$, which is consistent with hospital records of women born between 1923 and 1930 in Hertfordshire (mean $3.42 \mathrm{~kg}$, SD not provided), ${ }^{31}$ and also with women in the 1946 British birth cohort (mean (SD) 3.32 (0.49) kg; personal communication from Professor D Kuh, University College London). Participants who provided birth weight data in our study had better lung function, were from more affluent social groups, were taller, and were less likely to be current smokers than those who did not provide birth weight data. However, inclusion of these variables in the regression models should yield unbiased estimates. In a number of studies self-reported birth weight has been found to correlate well with hospital records (correlation coefficients in the range of $0.64-0.86$ ), although absolute levels of accuracy may be poor. ${ }^{23}$ It is difficult to see how objective measurements such as lung function could influence birth weight recall, and therefore misclassification is likely to be non-differential and may, as a result, have diluted the associations. Our null results may therefore reflect the use of self-reported birth weight.

\section{Fetal origins of adult lung function}

We identified 10 reports of the association between birth weight and lung function measured in adulthood, six of which reported a positive association between birth weight and lung function adjusted for age, height and smoking ${ }^{7-}$ 102627 and four of which, like our study, reported a null association. ${ }^{12-15}$ In reality, as fig 1 shows, there is little heterogeneity between the studies with most demonstrating weak positive but imprecise associations between birth weight and $\mathrm{FEV}_{1}$. Our study is in women only and there is some suggestion from fig 1 that our results differ from other studies in being closer to the null value (although there was no strong statistical evidence to support this). A weaker effect in our study compared with other studies could be due to the effect of non-differential bias resulting from our use of selfreported birth weight as discussed above but, in the Caerphilly study ${ }^{26}$ of men, self-report of birth weight in adulthood was also used and yet this study found a more positive association than that found in our study. Other studies included both sexes or were of men only. Thus, the weaker effect in our study may be explained by a weaker effect of birth weight on adult lung function in women than in men. Fetal growth rates differ between the sexes and in other areas it has been suggested that this results in different effects of fetal programming between the sexes. ${ }^{24}$ Just one study presented results stratified by sex (fig l), and there was no evidence from this study that the effect of birth weight on $\mathrm{FEV}_{1}$ differed between women and men. ${ }^{9}$

The magnitude of effect in individual studies and when these studies are pooled is modest. A $1 \mathrm{~kg}$ difference in birth weight is large and would be very difficult to obtain by modification of any known environmental risk factors, yet 
Table 4 Summary of published studies examining the association between birth weight and lung function

\begin{tabular}{|c|c|c|c|c|c|c|c|c|}
\hline $\begin{array}{l}\text { First author (year } \\
\text { of publication) }\end{array}$ & Study type & $\mathrm{N}$ & Country & $\begin{array}{l}\text { Age at lung } \\
\text { function tests }\end{array}$ & $\begin{array}{l}\text { Source of birth } \\
\text { weight data }\end{array}$ & $\begin{array}{l}\text { Main results (as } \\
\text { published) }\end{array}$ & $\begin{array}{l}\beta(\mathrm{SE}) \text { coefficient } \\
(\mathrm{I} / \mathrm{kg}) \text { used in } \\
\text { meta-analysis* }\end{array}$ & $\begin{array}{l}\text { Factors controlled } \\
\text { for }\end{array}$ \\
\hline Barker $(1991)^{7}$ & $\begin{array}{l}\text { Retrospective } \\
\text { cohort }\end{array}$ & 825 & England & $59-70$ & $\begin{array}{l}\text { Obstetric } \\
\text { records }\end{array}$ & $\begin{array}{l}\text { Change per } 1 \mathrm{lb} \text { birth } \\
\text { weight: } \\
\text { FEV: } 0.06 \text { I } \\
(0.02 \text { to } 0.09)\end{array}$ & $0.03(0.014)$ & $\begin{array}{l}\text { Age, height, } \\
\text { smoking, social } \\
\text { class at birth }\end{array}$ \\
\hline Strachan $(1994)^{27}$ & Prospective cohort & 1186 & $\begin{array}{l}\text { England \& } \\
\text { Wales }\end{array}$ & $34-35$ & Obtained at birth & $\begin{array}{l}\text { Positive linear trend } \\
\text { of } \mathrm{FEV}_{1} \text { across quarters } \\
\text { of birth weight } \\
(\mathrm{p}=0.011)\end{array}$ & Not available & $\begin{array}{l}\text { Sex, height, } \\
\text { smoking, father's } \\
\text { social class }\end{array}$ \\
\hline Frankel $(1996)^{26}$ & Prospective cohort & 1258 & Wales & $45-59$ & Self-report & $\begin{array}{l}\text { Positive linear trend of } \\
F V_{1} \text { across quarters } \\
(p=0.06)\end{array}$ & $0.047(0.023)$ & $\begin{array}{l}\text { Age, height } \\
\text { squared (male } \\
\text { only study) }\end{array}$ \\
\hline Stein $(1997)^{9}$ & $\begin{array}{l}\text { Birth cohort } \\
\text { follow-up }\end{array}$ & 286 & India & $38-59$ & $\begin{array}{l}\text { Obstetric } \\
\text { records }\end{array}$ & $\begin{array}{l}\text { Change per } 1 \mathrm{lb} \\
\text { birth weight: } \\
\mathrm{FEV}_{1} \text { in men: } 0.16 \mathrm{I} \\
(-0.02 \text { to } 0.33) \\
\mathrm{FEV}_{1} \text { in women: } 0.14 \mathrm{I} \\
(0.00 \text { to } 0.30)\end{array}$ & $0.06(0.03)$ & $\begin{array}{l}\text { Age, height, body } \\
\text { mass index, social } \\
\text { class, smoking } \\
\text { (results stratified } \\
\text { by sex) }\end{array}$ \\
\hline Shaheen $(1998)^{15}$ & $\begin{array}{l}\text { Retrospective } \\
\text { cohort }\end{array}$ & 239 & Scotland & $\begin{array}{l}\text { Mean (SD) } \\
57.6(4.3)\end{array}$ & $\begin{array}{l}\text { Obstetric } \\
\text { record }\end{array}$ & $\begin{array}{l}\text { Change per } \mathrm{kg} \\
\text { birth weight: } \\
\mathrm{FEV}_{1}: 0.036 \mathrm{I}(-0.074 \\
\text { to } 0.147) \\
\text { FVC: } 0.0101 \\
(-0.119 \text { to } 0.139)\end{array}$ & $0.036(0.057)$ & $\begin{array}{l}\text { Age, sex, height, } \\
\text { smoking and type } \\
\text { of spyrometer }\end{array}$ \\
\hline Lopuhaa $(2000)^{1 / 4}$ & $\begin{array}{l}\text { Retrospective } \\
\text { cohort }\end{array}$ & 726 & The Netherlands & 50 & Birth records & $\begin{array}{l}p \text { values for linear trends } \\
\text { across four categories of } \\
\text { birth weight: } \\
\text { FEV } 1: p=0.6 \\
\text { FVC: } p=0.6 \\
\text { FEV }_{1} / \text { FVC: } p=0.8\end{array}$ & $0.03(0.03)$ & Age, sex, height \\
\hline Cheung $(2001)^{13}$ & $\begin{array}{l}\text { Prospective birth } \\
\text { cohort }\end{array}$ & 120 & China & 30 & Birth records & $\begin{array}{l}p \text { values for linear trends } \\
\text { across seven categories } \\
\text { of birth weight: } \\
\text { FEV } 1: p=0.36 \\
\text { FVC: } p=0.87 \\
\text { FEV }_{1} / \text { FVC: } p=0.30\end{array}$ & Not available & Age, sex, height \\
\hline Boezen $(2002)^{36}$ & Prospective cohort & 590 & The Netherlands & $18-22$ & $\begin{array}{l}\text { Obstetric } \\
\text { records }\end{array}$ & $\begin{array}{l}\text { Change per } 100 \mathrm{~g} \\
\text { decrease in birth weight } \\
\text { FEV } 1:-0.013 \\
\text { (SE } 0.004 \text { ) }\end{array}$ & $0.13(0.04)$ & $\begin{array}{l}\text { Age, height, } \\
\text { smoking, maternal } \\
\text { smoking in } \\
\text { pregnancy, sex, } \\
\text { birth order, } \\
\text { gestational age }\end{array}$ \\
\hline Edwards $(2003)^{10}$ & $\begin{array}{l}\text { Record linkage } \\
\text { cohort study }\end{array}$ & 323 & Scotland & $45-50$ & $\begin{array}{l}\text { Obstetric } \\
\text { records }\end{array}$ & $\begin{array}{l}p \text { values for linear trends } \\
\text { across five categories of } \\
\text { birth weight: } \\
\text { FEV }_{1} \text { men: } p=0.04 \\
\text { FEV }_{1} \text { women: } p=0.01 \\
\text { FVC men: } p<0.01 \\
\text { FVC women: } p<0.01\end{array}$ & Not available & $\begin{array}{l}\text { Age, height, } \\
\text { weight, smoking, } \\
\text { deprivation } \\
\text { category, sex, } \\
\text { parity, gestational } \\
\text { age }\end{array}$ \\
\hline Laerum $(2004)^{16}$ & $\begin{array}{l}\text { Retrospective } \\
\text { cohort }\end{array}$ & 1514 & $\begin{array}{l}\text { Denmark, Estonia, } \\
\text { Iceland, Norway, } \\
\text { Sweden }\end{array}$ & $20-44$ & $\begin{array}{l}\text { Birth or } \\
\text { obstetric } \\
\text { records }\end{array}$ & $\begin{array}{l}\text { Change per } 500 \mathrm{~g} \text { birth } \\
\text { weight } \\
\text { FEV } 1: 0.45(-0.52 \\
\text { to } 1.41) \% \text { predicted } \\
\text { FVC: } 0.47(-0.52 \\
\text { to } 1.46) \% \text { predicted }\end{array}$ & $0.09(0.024)$ & $\begin{array}{l}\text { Age, sex, height, } \\
\text { prematurity, study } \\
\text { centre (country), } \\
\text { BMI, allergic } \\
\text { rhinitis, parental } \\
\text { and adult smoking } \\
\text { (the results in the } \\
\text { published study } \\
\text { were also adjusted } \\
\text { for birth length; the } \\
\text { results included in } \\
\text { our meta-analysis } \\
\text { were not adjusted } \\
\text { for birth length) }\end{array}$ \\
\hline
\end{tabular}

this large difference in birth weight was associated with a difference of just $0.05 \mathrm{l}$ in $\mathrm{FEV}_{1}$ in the pooled analysis. This compares with the difference of $-0.38 \mathrm{l}$ between women who were current smokers and those who had never smoked in the British Women's Heart and Health Study. However, whereas current smoking will have a direct effect on lung function, birth weight per se is unlikely to have a direct effect on adult lung function. Birth weight in these analyses is acting as a proxy marker for some other (environmental or genetic) exposure that influences birth size and has a lasting effect on adult lung function. While genetic factors are important determinants of birth size, and heritability studies suggest that there are important genetic determinants of adult lung function that are independent of atopic disease, cigarette smoking, height, age or sex,,$^{32-34}$ we are unaware of any candidate genes that are related both to birth weight and lung function and that could therefore explain their association. 
Lung function increases in healthy children reaching a maximum in late adolescence/early twenties, stays at this level throughout adulthood, and then begins to decline with age in late adulthood. ${ }^{35}$ Intrauterine exposures could affect this normal trajectory in a number of different ways. Exposures that result in retarded fetal growth may irrecoverably constrain the growth of an individual's airways and result in poorer lung function that persists into adulthood. ${ }^{5} \mathrm{In}$ this scenario a low birth weight individual would have a similar pattern of lung development across their life course, but would tend to have poorer lung function at any age compared with an individual of normal birth weight. Maternal smoking during pregnancy and maternal nutrition across her life course and during pregnancy may be important factors affecting fetal growth and lung development. ${ }^{5}$ All of the studies included in our meta-analysis had adjusted for participant smoking, but only one had adjusted for maternal smoking during pregnancy. ${ }^{36}$ Maternal smoking during pregnancy is a strong determinant of birth weight ${ }^{37}$ and could affect adult lung function via two pathways. Firstly, maternal smoking is strongly related to offspring smoking, ${ }^{38}$ which will have a direct effect on their lung function. If this were the only pathway through which maternal smoking affected adult lung function, then adjustment for the more proximal "own smoking" would adequately account for the effect of maternal smoking. However, there is evidence that maternal smoking during pregnancy has a direct effect on lung development and lung function in the offspring, irrespective of whether the offspring smokes, ${ }^{36}{ }^{39}$ providing a mechanism by which adult lung function might be related to maternal smoking during pregnancy. Independence of the effects of maternal smoking during pregnancy from birth weight on adult lung function was demonstrated by Boezen et al, ${ }^{36}$ but it is impossible from the results presented to determine the extent of attenuation of the birth weight association with adjustment for maternal smoking. If maternal smoking is an important influence, our null findings might be explained by the relatively older age of our participants compared with other studies which were of younger women, as female smoking rates were extremely low in Britain in the 1920s and 1930s (with fewer than $0.1 \%$ of women in the 20-40 year age range smoking during these decades ${ }^{40}$ ). Thus, in our study exposure to smoking during pregnancy simply did not arise for the vast majority of offspring and consequently could not provide a link between birth weight and adult lung function.

Postnatal factors such as acute respiratory infections might also affect lung growth and development differentially in low and normal birth weight infants, resulting in a slower increase in function during childhood and a lower adult plateau. Since respiratory infections are more common in those of low birth weight, this might provide another mechanism linking low birth weight to poorer lung function in later adulthood. Some support for this hypothesis is provided by one study in which adjustment for childhood respiratory infections attenuated the association between birth weight and adult lung function towards the null. ${ }^{15}$

One way to further explore the effect of intrauterine factors on lung development trajectories across the life course would be to examine the relationship of birth weight with repeated measurements of lung function taken within the same cohort across their life course. We are unaware of any study with repeated measurements of lung function that could determine whether the effect of birth weight varies with age.

In conclusion, our results suggest that birth weight is positively associated with lung function in adulthood. The effect is small but does add to the evidence of a role for intrauterine factors in lung growth and development.

\section{ACKNOWLEDGEMENTS}

The authors thank all of general practitioners and their staff who have supported data collection and the women who have participated in the study; Rita Patel, Carol Bedford, Alison Emerton, Nicola Frecknall, Karen Jones, Mark Taylor, Simone Watson, and Katherine Wornell for collecting and entering data; and Yoav Ben-Shlomo and Birger Laerum for providing additional information from their studies.

\section{Authors' affiliations}

D A Lawlor, S Ebrahim, G Davey Smith, Department of Social Medicine, University of Bristol, Bristol, UK

The British Women's Heart and Health Study is funded by the (UK) Department of Health. DA Lawlor is funded by a (UK) Department of Health career scientist award. The views expressed in this publication are those of the authors and not necessarily those of the Department of Health.

Conflict of interests: none

\section{REFERENCES}

1 Strachan DP. Ventilatory function, height, and mortality among lifelong nonsmokers. J Epidemiol Community Health 1992;46:66-70.

2 Hole DJ, Watt GC, Davey Smith G, et al. Impaired lung function and mortality risk in men and women: findings from the Renfrew and Paisley prospective population study. BMJ 1996;313:711-5.

3 Schunemann HJ, Dorn J, Grant BJ, et al. Pulmonary function is a long-term predictor of mortality in the general population: 29-year follow-up of the Buffalo Health Study. Chest 2000;1 18:656-64.

4 Barker DJP. Mothers, babies and health in later life. London: Churchill Livingstone, 1998.

5 Warner JO, Jones CA. Fetal origins of lung disease. In: Barker DJP, eds. Fetal origins of cardiovascular and lung disease. New York: Marcel Dekker, 2001:297-321.

6 Lawlor DA, Ben-Shlomo Y, Leon DA. Pre-adult influences on cardiovascular disease. In: Kuh D, Ben-Shlomo Y, eds. A life course approach to chronic disease epidemiology. Oxford: Oxford University Press, 2004:41-76.

7 Barker DJ, Godfrey KM, Fall C, et al. Relation of birth weight and childhood respiratory infection to adult lung function and death from chronic obstructive airways disease. BMJ 1991;303:671-5.

8 Rona RJ, Gulliford MC, Chinn S. Effects of prematurity and intrauterine growth on respiratory health and lung function in childhood. BMJ 1993;306:817-20.

9 Stein $\mathrm{CE}$, Kumaran $\mathrm{K}$, Fall CH, et al. Relation of fetal growth to adult lung function in south India. Thorax 1997;52:895-9.

10 Edwards CA, Osman LM, Godden DJ, et al. Relationship between birth weight and adult lung function: controlling for maternal factors. Thorax 2003:58:1061-5.

11 Boezen HM, Vonk JM, van Aalderen WM, et al. Perinatal predictors of respiratory symptoms and lung function at a young adult age. Eur Respir $J$ 2002;20:383-90.

12 Matthes JW, Lewis PA, Davies DP, et al. Birth weight at term and lung function in adolescence: no evidence for a programmed effect. Arch Dis Child 1995;73:231-4.

13 Cheung YB, Karlberg JP, Low L, et al. Birth weight and adult lung function in China. Thorax 2001;56:85.

14 Lopuhaa CE, Roseboom TJ, Osmond C, et al. Atopy, lung function, and obstructive airways disease after prenatal exposure to famine. Thorax 2000;55:555-61.

15 Shaheen SO, Sterne JA, Tucker JS, et al. Birth weight, childhood lower respiratory tract infection, and adult lung function. Thorax 1998;53:549-53.

16 Laerum BN, Svanes C, Gulsvik A, et al. Is birth weight related to lung function and asthma symptoms in Nordic-Baltic adults? Respir Med 2004;98:611-8.

17 Kramer MS. Socioeconomic determinants of intrauterine growth retardation. Eur J Clin Nutr 1998;52(Suppl 1):S29-32.

18 Lawlor DA, Ebrahim S, Davey Smith G. Association between self-reported childhood socioeconomic position and adult lung function: findings from the British Women's Heart and Health Study. Thorax 2004;59:199-203.

19 Lawlor DA, Bedford C, Taylor M, et al. Geographic variation in cardiovascular disease, risk factors and their control in older women: British Women's Heart and Health Study. J Epidemiol Community Health 2003;57:134-40.

20 Lawlor DA, Ebrahim S, Davey Smith G. The association between components of adult height and type II diabetes and insulin resistance: British Women's Heart and Health Study. Diabetologia 2002;45:1097-106.

21 Lawlor DA, Davey Smith G, Ebrahim S. Birth weight is inversely associated with coronary heart disease in post-menopausal women: findings from the British Women's Heart and Health Study. J Epidemiol Community Health 2004;58:120-5.

22 Cole TJ. Linear and proportional regression models in the prediction of ventilatory function. J R Stat Soc Ser A 1975;138:297-324.

23 Allen DS, Ellison GT, dos SS, I, et al. Determinants of the availability and accuracy of self-reported birth weight in middle-aged and elderly women. Am J Epidemiol 2002;155:379-84. 
24 Lampl M, Jeanty P. Timing is everything: a reconsideration of fetal growth velocity patterns identifies the importance of individual and sex differences. Am J Human Biology 2003;15:667-80.

25 Sterne JAC, Bradburn MJ, Egger M. Meta-analysis in Stata. In: Egger M, Davey Smith G, Altman DG, eds. Systematic reviews in health care. Metaanalysis in context. London: BMA Books, 2001:347-69.

26 Frankel S, Elwood P, Sweetnam P, et al. Birthweight, body mass index in middle age, and incident coronary heart disease. Lancet 1996;348:1478-80

27 Strachan DP, Griffiths JM, Anderson HR, et al. Association of intrauterine and postnatal growth with ventilatory function in early adult life. Thorax 1994;49:1052P.

28 Alberman $\mathrm{E}$, Filakti $\mathrm{H}$, Williams $\mathrm{S}$, et al. Early influences on the secular change in adult height between the parents and children of the 1958 birth cohort. Ann Hum Biol 1991;18:127-36.

29 Law CM, Barker DJP, Osmond C, et al. Early growth and abdominal fatness in adult life. J Epidemiol Community Health 1992;46:184-6.

30 Erens B, Primatesta P. Health Survey for England 1998: Cardiovascular disease. London: The Stationery Office, 1999.

31 Fall CH, Osmond C, Barker DJ, et al. Fetal and infant growth and cardiovascular risk factors in women. BMJ 1995;310:428-32.

32 Wilk JB, DeStefano AL, Arnett DK, et al. A genome-wide scan of pulmonary function measures in the National Heart, Lung, and Blood Institute Family Heart Study. Am J Respir Crit Care Med 2003;167:1528-33.
33 Gottlieb DJ, Wilk JB, Harmon M, et al. Heritability of longitudinal change in lung function. The Framingham study. Am J Respir Crit Care Med $2001 ; 164: 1655-9$

34 Palmer LJ, Knuiman MW, Divitini ML, et al. Familial aggregation and heritability of adult lung function: results from the Busselton Health Study. Eur Respir J 2001;17:696-702.

35 Strachan DP, Sheikh A. A life course approach to respiratory and allergic diseases. In: Kuh D, Ben-Shlomo Y, eds. A life course approach to chronic disease epidemiology.2nd edn. Oxford: Oxford University Press, 2004:240-59.

36 Boezen HM, Vonk JM, van Aalderen WM, et al. Perinatal predictors of respiratory symptoms and lung function at a young adult age. Eur Respir J 2002;20:383-90.

37 Kramer MS. Determinants of low birth weight: methodological assessment and meta- analysis. Bull WHO 1987:65:663-737.

38 Lawlor DA, O'Callaghan MJ, Mamun AA, et al. Early life predictors of adolescent smoking: findings from the Mater-University Study of Pregnancy and its outcomes. Paediatr Perinatal Epidemiol 2005 (in press).

39 Upton MN, Watt GC, Davey Smith G, et al. Permanent effects of maternal smoking on offsprings' lung function. Lancet 1998;352:453.

40 Forey B, Hamling J, Lee P, et al. International smoking statistics, 2nd edn.A collection of historical data from 30 economically developed countries. Oxford: Wolfson Institute of Preventive Medicine and Oxford Medical Publications, 2002

\section{LUNG ALERT}

Lung stem cells as a possible origin of cancer

$\Delta \mathrm{Kim}$ CFB, Jackson EL, Woolfenden AE, et al. Identification of bronchioalveolar stem cells in normal lung and lung cancer. Cell 2005;121:823-35

$\mathrm{E}$ pithelial stem cell populations are thought to exist in anatomically and functionally distinct locations within the lung, as suggested by earlier observations of lung injury models. This observational study looked at mouse models to support the hypotheses that stem cell populations exist in the distal lung, that these stem cells act to maintain bronchiolar Clara and alveolar cells, and that their transformation may give rise to lung adenocarcinomas.

In adult mice, bronchioalveolar stem cells (BASC) were identified at the bronchioalveolar duct junction (BADJ) within the terminal bronchioles by specific cell markers. These cell markers were distinct to Clara (CCA), alveolar (SP-C), and stem cell populations (Sca-1), and cells positive for all three markers at the BADJ were classified as BASC.

Direct effects of naphthalene (specific ablation of Clara cells) and bleomycin (specific alveolar damage) treatment on cell lineages were observed. BASC were shown to increase significantly in number 1 week following naphthalene treatment $(p=0.03)$ and 2 weeks following bleomycin treatment $(p=0.01)$. Proliferation of the BASC population was felt to directly mirror the increase in epithelial repair required secondary to the ablated Clara and alveolar cell populations.

Clara and alveolar type 2 cells are widely thought to be the precursor cells in lung adenocarcinomas. In this study, mouse models (Lox-K-Ras mice) showed that BASC numbers were increased, even in the earliest tumorigenic lesions (adenomas), and increased further during tumour progression. These findings support the existence of stem cell populations within the distal lung. The observed proliferation of BASC during epithelial repair in vivo, linkage to lung tumours, and properties of self-renewal and multipotent differentiation in culture are all important features of stem cell populations that were observed in the proposed BASC population.

Identification of bronchioalveolar stem cells in future studies may permit directed differentiation of these cells, allowing regeneration of defective epithelium in chronic lung diseases. It may also allow more effective early identification of lung carcinomas with the opportunity for directed treatment strategies against hyperproliferating BASC. Further work is required to elucidate the role of BASC in adenocarcinomas of the lung.

S E A Fairbairn

Clinical Research Fellow, Royal Gwent Hospital, Newport, UK; docsara2001@yahoo.com 